\title{
Investigation of June 2020 giant Saharan dust storm using remote sensing observations and model reanalysis
}

\author{
A. Asutosh ${ }^{1}$, V. Vinoj ${ }^{1}$ and M. Nuncio ${ }^{2}$ \\ ${ }^{1}$ School of Earth, Ocean and Climate Science Indian Institute of Technology Bhubaneswar, \\ Bhubaneswar, Odisha, India \\ ${ }^{2}$ National Centre for Polar and Ocean Research (NCPOR), Ministry of Earth Sciences, Goa, \\ India
}

Correspondence: asutosh.acharya@gmail.com

\begin{abstract}
This paper investigates the characteristics and impact of a major Saharan dust storm during June $14^{\text {th }}-19^{\text {th }} 2020$ to atmospheric radiative and thermodynamics properties over the Atlantic Ocean. The event witnessed the highest ever aerosol optical depth (close to 2 during the peak of the storm) for June since 2002. The satellites and high-resolution model reanalysis products well captured the origin, spread and the effects of the dust storm. The Cloud-Aerosol Lidar and Infrared Pathfinder Satellite Observation (CALIPSO) profiles, lower angstrom exponent values $(\sim 0.12)$ and higher aerosol index value $(>4)$ tracked the presence of elevated dust. It was found that the dust AOD was as much as $250-300 \%$ higher than their climatology resulting in an atmospheric radiative forcing $\sim 200 \%$ larger. As a result, elevated warming ( 8-16\%) was observed, followed by a drop in relative humidity $(2-4 \%)$ in the atmospheric column, as evidenced by both in-situ and satellite measurements. Quantifications such as these for extreme dust events provide significant insights that may help in understanding their climate effects, including improvements to dust simulations using chemistry-climate models.
\end{abstract}

Keywords: Dust storm, Aerosols, Satellite remote sensing, Radiative forcing, Thermodynamics

\subsection{Introduction}

Dust/Mineral dust is one of the important components of the atmospheric aerosols in the earth system. Dust contributes nearly $30 \%$ to the optical thickness and more than $70 \%$ to the total aerosol mass load (Kinne et al., 2006). The dust aerosol has both scattering and absorption characteristics in the solar and terrestrial radiation spectrum. It has the potential to perturb the radiation budget both by direct and indirect effects (Haywood et al., 2005; Hsu et al., 2000).Dust possesses a broad range of impacts starting from local and global climate to human health (Mahowald et al., 2010; Pandey et al., 2017; Pérez et al., 2006; Tiwari et al., 2019; Vinoj et al., 2014), biogeochemistry in the ocean (Fung et al., 2000; Jickells et al., 2005) and even on tropical cyclones (Pan et al., 2018). Also, outbreaks of desert dust impact the air quality both locally and remotely (Milford et al., 2019; Querol et al., 2009)

North Africa alone contributes more than $50 \%$ of global dust emission and is considered the active global dust source region (Ginoux et al., 2012; Goudie and Middleton, 2001). During summer, the dust storm events are frequent over North-west Africa. The Saharan heat low (SHL) is the dominant atmospheric circulation pattern over North Africa (Francis et al., 2020; W Wang, 2015). The temperature gradient between the Gulf of Guinea (moist air) and inland 
SHL associated thermal winds develops the African Easterly Jet (AEJ). The AEJ usually peaks at $700 \mathrm{hPa}$ and occurs north of $10^{\circ} \mathrm{N}$ playing a vital role in the long range transport of dust from storms over these regions (Bou Karam et al., 2014). Dust storm often occurs when a strong wind blows over loose sands. As a response, the dust gets injected high in the atmosphere. As dust reaches the level of AEJ (Von Engeln and Teixeira, 2013), it then gets transported to the west over the Atlantic Ocean (Engelstaedter et al., 2006; Touré et al., 2012).

In June 2020, an anomalous pressure pattern developed over North Africa and the adjacent oceanic region due to the circumpolar northern hemispheric wave train (Francis et al., 2020).This further intensified surface wind and AEJ. As a response, June 14-19, 2020, witnessed a massive dust storm over the Sahara desert resulting in huge amount of dust being lifted to the atmosphere. In particular, this storm was reported to be the strongest ever (June reference) since 2002 since the start of the satellite era. It reduced visibility across tropical Atlantic regions and got transported as far as the east coast of the USA, deteriorating the local air quality. This dust event was also shown to have reduced the sea surface temperature by $\sim 0.4^{\circ} \mathrm{C}$ in the tropical Atlantic Ocean (https://yaleclimateconnections.org/2020/06/saharandust-cloud-was-most-intense-in-decades/).

Satellite remote sensing techniques are widely used to study aerosols and dust storms worldwide (Bran et al., 2018; Dey et al., 2004; Kaskaoutis et al., 2007; Kedia et al., 2018; Namdari et al., 2018) .In recent years, advancements of model reanalysis products add more information in detecting aerosol source, their types and various impacts (Pakszys and Zielinski, 2017; Pandey et al., 2017; Penna et al., 2018; Sanap, 2021) .

This study aims to characterise and investigate the impact of the giant Saharan dust storm during 14-19 June 2020. The state of the art remote sensing datasets and model reanalysis are used to infer the possible changes in the aerosol properties, large scale radiative and thermodynamic effects. Section 2 explains the details of the data and methodology used in this study. The characteristic features of the dust storm are elucidated in section 3 . The regional and local impacts of the dust storm are outlined in section 4 followed by summary and conclusion.

\subsection{Data and methodology}

We have used datasets from Moderate Resolution Imaging Spectroradiometer (MODIS) (Remer et al., 2005), Atmospheric infrared sounder (AIRS) (Yue et al., 2020), Ozone monitoring instrument (Levelt et al., 2006),Cloud-aerosol lidar and infrared pathfinder satellite observation (CALIPSO) (Proestakis et al., 2018), Modern-Era Retrospective Analysis for Research and Application - version 2 (MERRA-2) reanalysis (Gelaro et al., 2017), Copernicus Atmosphere Monitoring Service (CAMS) reanalysis (Pakszys and Zielinski, 2017). Further, we have used the datasets of radiosonde provided by the University of Wyoming at the location Guimar-Tenerife (Milford et al., 2019). All the datasets (except radiosonde data) are interpolated to MODIS resolution $\left(1^{\circ} \times 1^{\circ}\right)$ for comparison. All the analysis were carried out for the domain comprising north-western Africa and eastern to central Atlantic $\left(5^{\circ} \mathrm{N}-30^{\circ} \mathrm{N}, 50^{\circ} \mathrm{W}-10^{\circ} \mathrm{W}\right.$, marked as Yellow box in Fig.1). Brief details about the individual datasets are provided below. 


\subsection{Moderate Resolution Imaging Spectroradiometer (MODIS)}

The Moderate Resolution Imaging Spectroradiometer (MODIS) as a part of Terra/Aqua satellites provides daily aerosol products worldwide (Levy et al., 2010; Namdari et al., 2018). With a view scan of $\pm 55^{\circ}$, it is present at orbit $700 \mathrm{~km}$ above the globe. It has spectral ranges of $0.41-15 \mu \mathrm{m}$ at 36 different bands, ranging from visible to thermal IR (Levy et al., 2010; Remer et al., 2005) . The datasets are commonly used to study aerosol optical properties over both land and ocean surfaces. The daily mean of the Combined Dark Target and Deep Blue AOD at $0.55 \mu \mathrm{m}$ for land and ocean (level 3) is used for this study. MODIS AOD is extensively used to investigate dust storms and other aerosol related studies (Kumar et al., 2015; Namdari et al., 2018; Tiwari et al., 2019). More details about MODIS aerosol and other products can be obtained at http://modis.gsfc.nasa.gov.

\subsection{Ozone monitoring instrument (OMI)}

The single scattering albedo (SSA), UV aerosol index (UVAI/AI, 354nm) and AOD $(500 \mathrm{~nm})$ are used from the ozone monitoring Instruments (OMI). The instrument is on-board Aura satellite. It uses near UV (OMAERUV) algorithms for aerosol retrieval (Curier et al., 2008; Levelt et al., 2006; Torres et al., 2007). The original datasets have $0.25^{\circ} \mathrm{x} 0.25^{\circ}$ spatial resolution and are level 3 global gridded product. The SSA plays essential roles in calculating aerosol radiative forcing. SSA ranges between $0-1$ for entirely absorbing and completely scattering types of aerosols. The AI is calculated using spectral contrast at 331 and 360 radiance (Curier et al., 2008). The AI is highly sensitive to absorbing aerosols and varies linearly with AOD (Hsu et al., 1999). OMI UV-AI provides important information towards investigations of aerosols as well as dust storm events (Kaskaoutis et al., 2013; Torres et al., 2007) . The positive values of UVAI/AI indicate the presence of absorbing aerosols (like dust and smoke) (Herman et al., 1997; Kaskaoutis et al., 2010). On the other hand, negative values provide information about the dominance of scattering aerosols (e.g. sea salt, sulphate aerosols) in the atmospheric column (Gharai et al., 2013).

\subsection{Atmospheric infrared sounder (AIRS)}

AIRS is a part of NASA's "A train satellite" and placed on Aqua satellite (Yue et al., 2020). It provides accurate information about the atmospheric profiles of thermodynamics variables like temperature and humidity (Dessler et al., 2008). It also measures greenhouse gases like ozone, carbon dioxide, and methane. For this study, version $7,1^{\circ} \times 1^{\circ}$ resolution (latitudelongitude grids) datasets are used to investigate the relative humidity and temperature.

\subsection{Cloud-aerosol lidar and infrared pathfinder satellite observation (CALIPSO)}

The space lidar Cloud-aerosol lidar and infrared pathfinder satellite observation (CALIPSO) is widely utilized to study the vertical profile of dust and other aerosols worldwide (Filonchyk et al., 2019; Proestakis et al., 2018). The details about the retrieval algorithm can be found in Winker et al. (2003).CALIPSO has a 16 days repeat cycle and can observe aerosols over bright surfaces during clear and thin cloudy conditions. For this study, the CALIOP level 2 Ver. $3.4 \mathrm{x}$ data products are used to investigate the vertical extent of dust during the storm event.

\subsection{MERRA-2 Reanalysis}

The Modern-Era Retrospective Analysis for Research and Application - version 2 (MERRA2) provides data beginning in 1980 (Buchard et al., 2017) following the original MERRA 
reanalysis. The Goddard Earth Observing System-5 (GEOS-5) atmospheric general circulation model with 3DVar data assimilation system is used to prepare MERRA-2 datasets (Molod et al., 2015). The GEOS-5 model resolution is roughly $0.5^{\circ} \times 0.625^{\circ}$ in latitude and longitude, with 72 hybrid-eta layers. The aerosol data assimilation uses reflectance from the Advanced Very-High-Resolution Radiometer (AVHRR) sensor (1979-2002) (Heidinger et al., 2014), MODIS on Terra and Aqua, AOD retrievals from MISR (2000-2014) (Kahn et al., 2005) and aerosol measurements from AERONET (Holben et al., 1998). We have used the AOD, Dust AOD, Angstrom parameter (ANG) and radiative forcing parameters from the MERRA-2 reanalysis

2.6 CAMS reanalysis

The CAMS (Copernicus Atmosphere Monitoring Service) datasets is the largest global reanalysis datasets for atmospheric compositions (Inness et al., 2013) . It uses the ECMWF's Integrated Forecasting System (IFS), with 60 hybrid sigma/pressure levels along with a 4DVAr data assimilation procedure. The IFS uses 12 prognostic variables (11 aerosol mass mixing ratios and one precursor - SO2) and assimilates both the satellite and in situ data. The model uses various schemes for simulating Dust, sea salt and other gaseous precursors. The assimilated observations include AOD from the MODIS instruments on board the Terra and Aqua satellites, both over the ocean and dark land surface. The CAMS AOD is well validated by independent observations and with satellite datasets (Pakszys and Zielinski, 2017). AOD and Dust AOD from CAMS are used in this study.

\subsection{Radiosonde observations}

The radiosonde observation data $(00 \mathrm{Z}$ and $12 \mathrm{Z})$ provided by the University of Wyoming (Milford et al., 2019) is used to study the upper atmospheric thermodynamic state (i.e., temperature and relative humidity structure). We utilize the observations from GuimarTenerife (Station latitude: $28.47^{\circ} \mathrm{N}$ Station longitudes: $-16.38^{\circ} \mathrm{W}$ ) and is close to the dust storm's origin.

\subsection{DREAM model simulations}

DREAM (Dust Regional Atmospheric Modelling) is a 3D model that simulates all major processes (emission, transport and removal) of mineral dust aerosol (Nickovic et al., 2001). The Barcelona Supercomputing Centre (BSC) made the model simulations available, hence popularly called the BSC-DREAM model. The model uses the thermal state of the atmosphere, near-surface winds, soil properties, and vegetation covers etc., to simulate dust. The model has proven accuracy in predicting dust storm events (Ajtai et al., 2020; Amiridis et al., 2009; Basart et al., 2012; Pérez et al., 2006; Tiwari et al., 2019) and is well-validated with datasets from various satellite observations and observational network (Haustein et al., 2009; Pérez et al., 2006; Țîmpu et al., 2020).

\subsection{Aerosol Radiative forcing (ARF) Calculation}

The presence of aerosols over a region interacts with the radiative balance in various ways. ARF is the change in solar and terrestrial flux with and without the aerosols. The strength and nature of ARF at the top (TOA) bottom (SUR) and in the atmospheric column (ATM) have various environmental implications (Penna et al., 2018). MERRA-2 simulated radiative fluxes have shown good agreements with CERES satellite radiation data products (Zhang et al., 2020) . To calculate the clear sky aerosol radiative forcing using MERRA-2 fourth assimilation stream hourly data (MERRA-2_400.tavg1_2d_rad_Nx), we adopted the methodology from Penna et al.,(2018). The mathematical representation of the calculation of ARF is as follows

$$
A R F_{\text {SUR }}=(\text { SWGNTCLR }+ \text { LWGNTCLR })-(\text { SWGNTCLRCLN }+ \text { LWGNTCLRCLN })
$$




$$
\begin{aligned}
& A R F_{T O A}=(\text { SWTNTCLR }+ \text { LWTUPCLR })-(\text { SWTNTCLRCLN }+ \text { LWTUPCLRCLN }) \\
& A R F_{A T M}=A R F_{T O A}-A R F_{S U R}
\end{aligned}
$$

SW/LW stands for shortwave/ longwave, GN/TN stands for surface and top of the atmosphere net radiation flux, whereas CLR/CLN stands for clear sky and clear sky with no aerosols respectively. More details can be found in Penna et al., (2018) and Sanap( 2021)

To calculate the climatology, a total of five years (2015-2019) of each dataset have been used covering the dates of the events.

\subsection{Results and discussion}

\subsection{Observation of the dust storm from space}

Fig. 1 shows the time evolution of dust storm using the satellite image of MODIS and dust scores from AIRS. The images are produced from the EOSDIS worldview (https://worldview.earthdata.nasa.gov/ ). The dust storm started on $14^{\text {th }}$ June and continued further until $19^{\text {th }}$ June 2020 . The high values of dust scores $(>380)$ show the spatial spread of the dust in the atmosphere. It may be observed that dust (brown colour) spread across a large region covering north-west African landmass and many parts of the tropical Atlantic Ocean covering several degrees of latitude and longitudes.
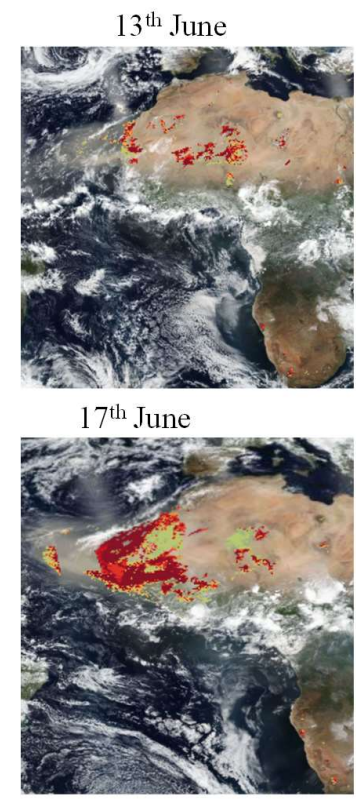

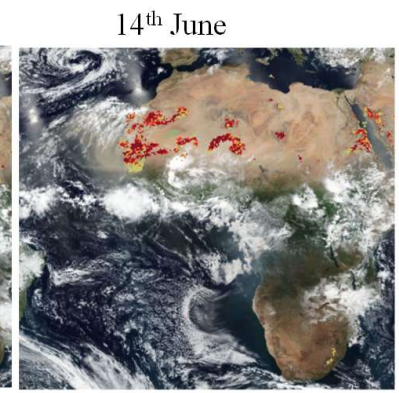

$18^{\text {th }}$ June

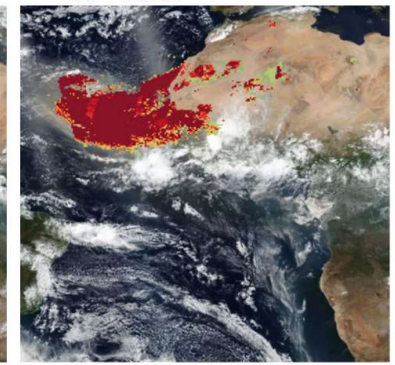

$15^{\text {th }}$ June

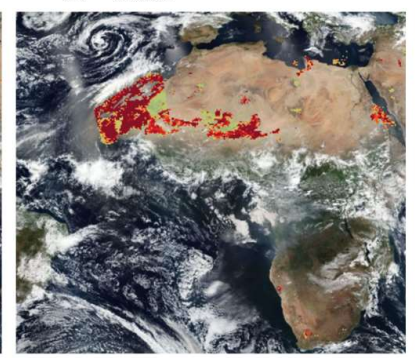

$19^{\text {th }}$ June

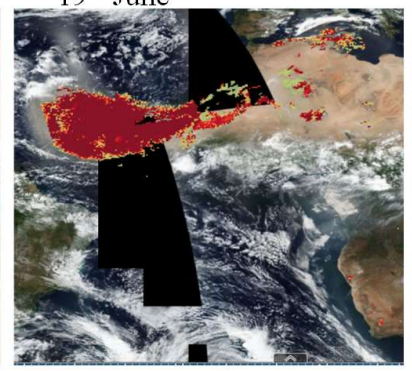

Dust Score

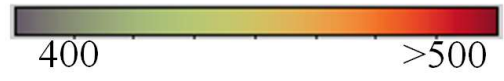

Fig.1. MODIS visible imagery indicating the evolution and transport of dust storm over the tropical Atlantic ocean. The brown colour indicates dust and the white shows clouds. The colour bar shows the value of the dust score from AIRS Level 2 datasets. The yellow box indicates the region of interest used for further analysis. 
The BSC-Dream model simulations show higher values (ranges from 100-1000 $\mu \mathrm{gm}^{-3}$ ) of dust concentration over the north-western African regions (Fig. S1). Such higher ranges are usually expected for dust storm cases as reported in earlier studies (Aher et al., 2014; Pérez et al., 2006; Tiwari et al., 2019).

\subsection{Multiplatform investigations of dust storm characteristics}

The AOD is a measure of solar attenuation by the particles in the atmosphere (dust, smoke haze etc.). A higher value of AOD indicates higher loads of atmospheric pollutants. AOD has been used as a matrix to investigate dust storm and pollution studies (Akinyoola et al., 2019; Singh et al., 2016; Tulet et al., 2008). The area-averaged $\left(5^{\circ} \mathrm{N}-30^{\circ} \mathrm{N}, 50^{\circ} \mathrm{W}-10^{\circ} \mathrm{W}\right)$ AOD values for June 2020 is shown in Fig. 2 from four different platforms. The values in the shaded regions are representing the period of the dust storm. The high AOD values during 14-19 June 2020 support the start and intensification of the dust storm. The aerosol optical depth values from satellites (MODIS and OMI in Fig 2a-b) show mean values higher than 1 and the maximum beyond 1.5. The OMI-AOD values are slightly higher than MODIS AOD possibly due to the spectral dependence of AOD as OMI (MODIS) measures AOD at 500nm $(550 \mathrm{~nm})$. The higher AOD values indicate the severity of the storm. High values of AOD have also been reported during other dust storm events (Dey et al., 2004; Tulet et al., 2008). The reanalysis AOD (Fig 2c-d) on the other hand, captures the dust event successfully; however, the values are a bit underestimated compared to the satellite observations. The maximum aerosol optical depth values are close to 1.5 for both MERRA-2 and CAMS reanalysis. The dust storm dissipated after $20^{\text {th }}$ June 2020, with a drastic decline in AOD compared, to the storm period (Fig.2). 

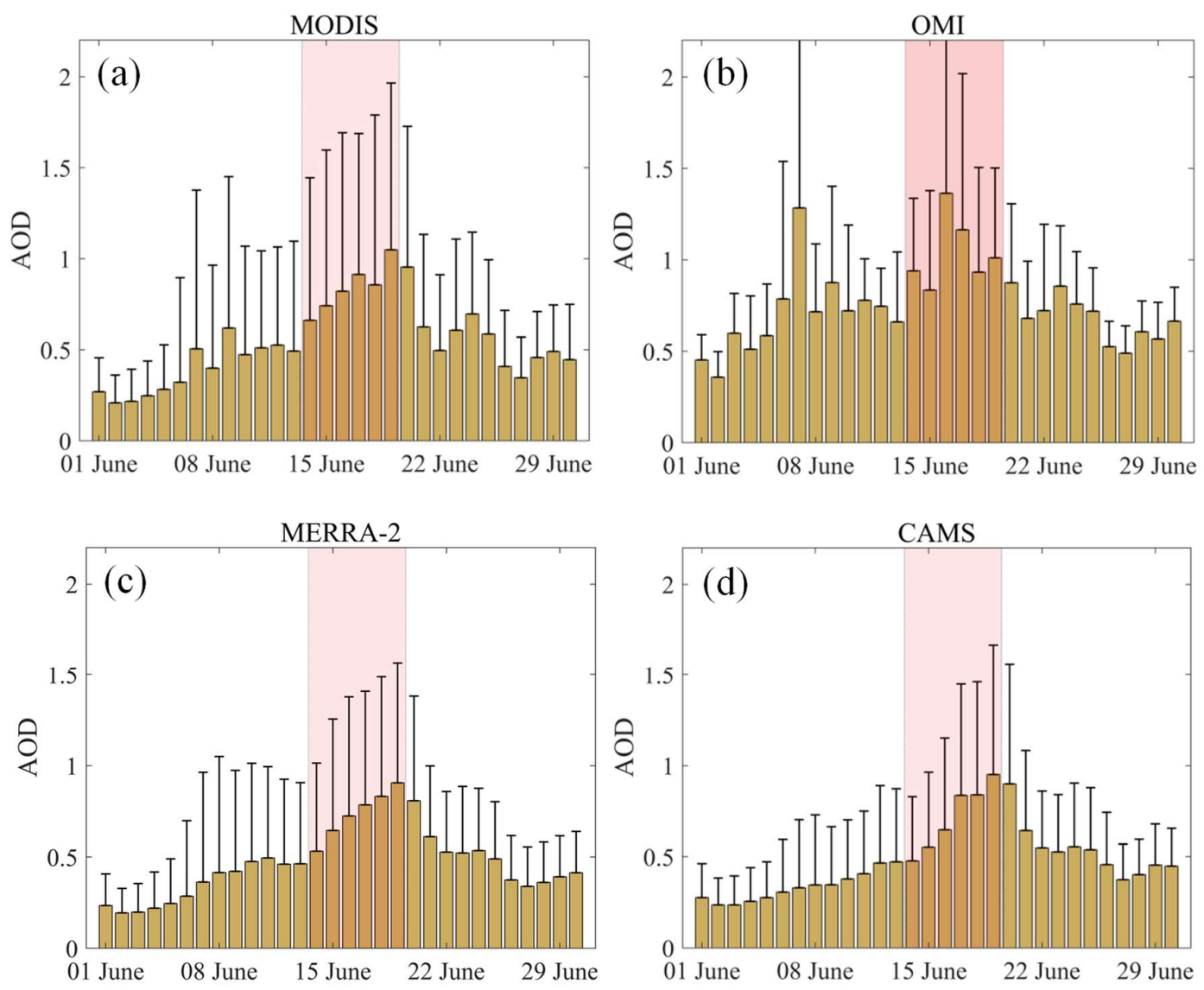

Fig.2. Area averaged time series of aerosol optical depth (AOD) during June 2020 from (a) MODIS, (b) OMI, (c) MERRA-2 and (d) CAMS. The shade is indicating the period of the dust storm (14-19, June 2020). The error bars indicate $+1 \sigma$ of the daily datasets over the selected area of interest.

\subsection{Inter-comparisons of $A O D$}

The AOD from reanalysis (MERRA-2 and CAMS) are compared with MODIS AOD to investigate their variability during the study period (June 1-30, 2020) and are shown in Fig 3a-b. It may be noted that both MERRA-2 and CAMS AOD show a statistically significant correlation with MODIS AOD (Pearson's $\mathrm{r}=0.97$ and 0.93 respectively). A high positive correlation indicates high confidence in the modelled/reanalysis AOD's. This provides confidence that the reanalysis AOD also can serve better to investigate such high pollution episodes. The intensification of AEJ and surface winds could also have produced the sea salt AOD over the ocean. However, the regression analysis between reanalysis based total AOD and their corresponding DUST AOD (Fig 2c-d) shows the dominance of dust over the study region $(\mathrm{R} 2=0.99$ and 0.98 respectively for MERRA-2 and CAMS) 

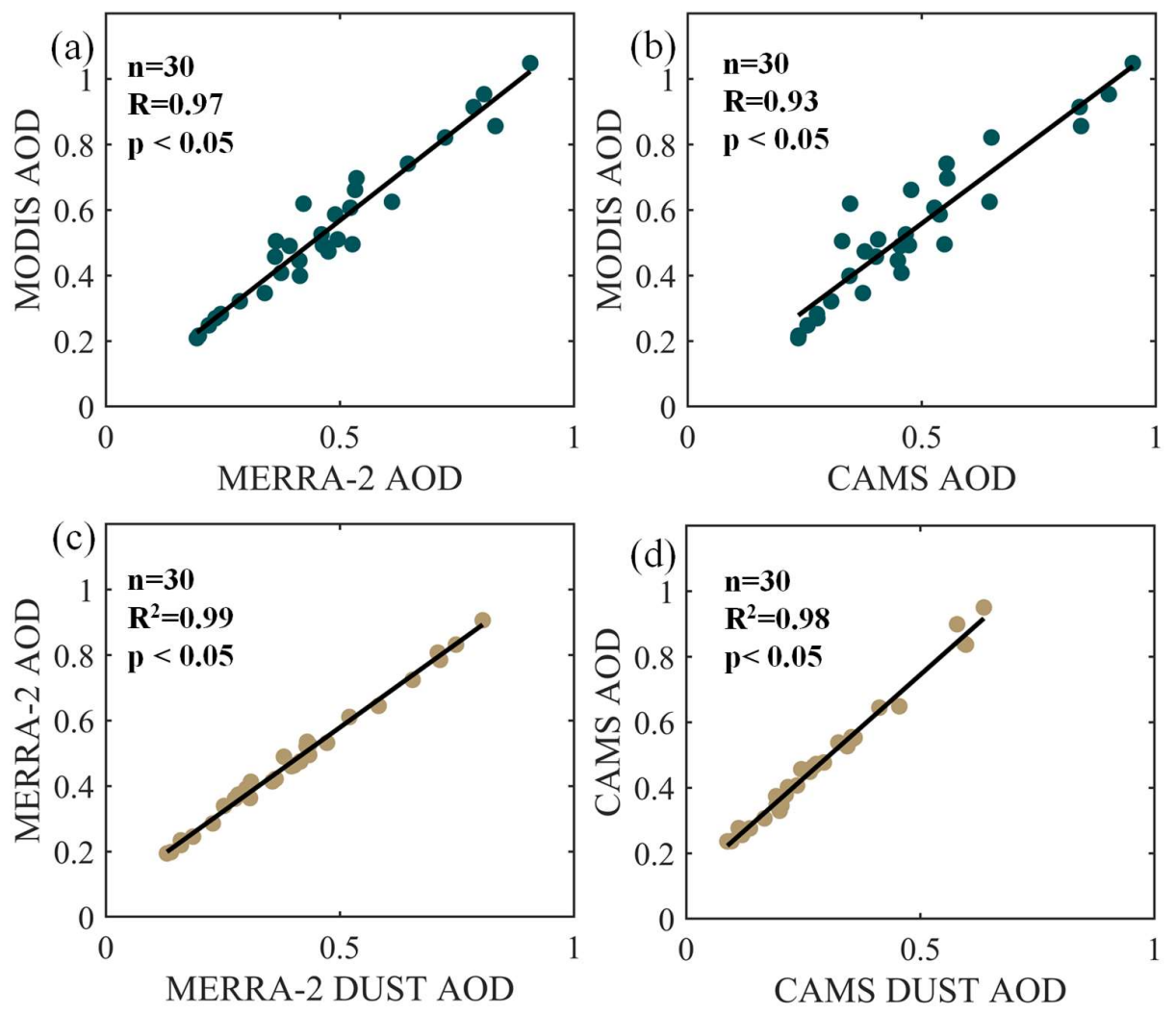

Fig.3.Correlations in AOD between (a) MODIS and MERRA-2, (b) MODIS and CAMS, (c) percentage variation in MERRA-2 AOD due to dust AOD (d) percentage variation in CAMS AOD due to dust. The datasets are used from 1-30 June 202

\subsection{ANG, AI and SSA characteristics}

The angstrom parameter (ANG) explains the spectral dependence of aerosols. Additionally, it serves as a proxy for the size of the pollutant present in the atmosphere. Before the dust storm, the mean ANG was $\sim 0.3$ (Fig 4a), which dropped to 0.12 during the dust storm event (Table 1). This indicates the dominance of coarser mode particles. The higher value of AOD (Fig 2) and lower ANG values is a typical signature of dust (dominance of coarse mode) event as reported by many earlier studies (Dey et al., 2004; Gautam et al., 2009; Prasad et al., 2007). Please note that the ANG (AOD) during storm event was comparatively lower (higher) than the pre-dust storm values. This is obvious as atmospheric dust removals take a certain time and favourable condition to happen. The prolonged drier atmosphere and stability (discussed separately) might have hindered the usual dust removal time. Also, this is normally a dust dominated region with frequent incursion from the African deserts.

The aerosol Index (UV-AI or AI) along with AOD provides important information about absorbing aerosols (i.e. smoke of dust) in the atmosphere. The AI values are averaged over the area same as AOD and presented in Fig 2b. The AI values picked up just after $13^{\text {th }}$ June and attained the maximum values in the ranges between $\sim 2$ to 4 . Relatively higher AOD and AI (like this event) are signatures of a severe dust storm. Additionally, AI values more than 3 indicate the presence of elevated dust (Aher et al., 2014; Badarinath et al., 2010; Prijith et al., 2013). The presence of high dust load during the dust storm is also being confirmed from our DUST AOD and column mass density analysis (Fig S2 and S3) and elevated dust observations using CALIPSO during the dust storm event (Fig S4). 
The OMI single scattering albedo (SSA) values show wavelength dependence and also depend on the composition of aerosols (Bergstrom et al., 2007). It explains the nature of aerosol types (absorbing/scattering), present in the atmosphere. The OMI derived SSA is well verified with ground-based measurements for various environmental and dust storm conditions (Alam et al., 2012; Gautam et al., 2011; Satheesh et al., 2009; Tiwari et al., 2015). The single scattering albedo values (Fig 4c) during the study period (except the storm event) were almost in the ranges $>0.86-0.9$, which indicates the presence of absorbing background dust. During the storm period, the mean values of SSA dropped below 0.85, suggesting the addition of absorbing aerosols in the atmosphere. The SSA dropped almost $2 \%$ to its climatological mean values over the study region during the giant dust storm episode 2020 (Table-1).
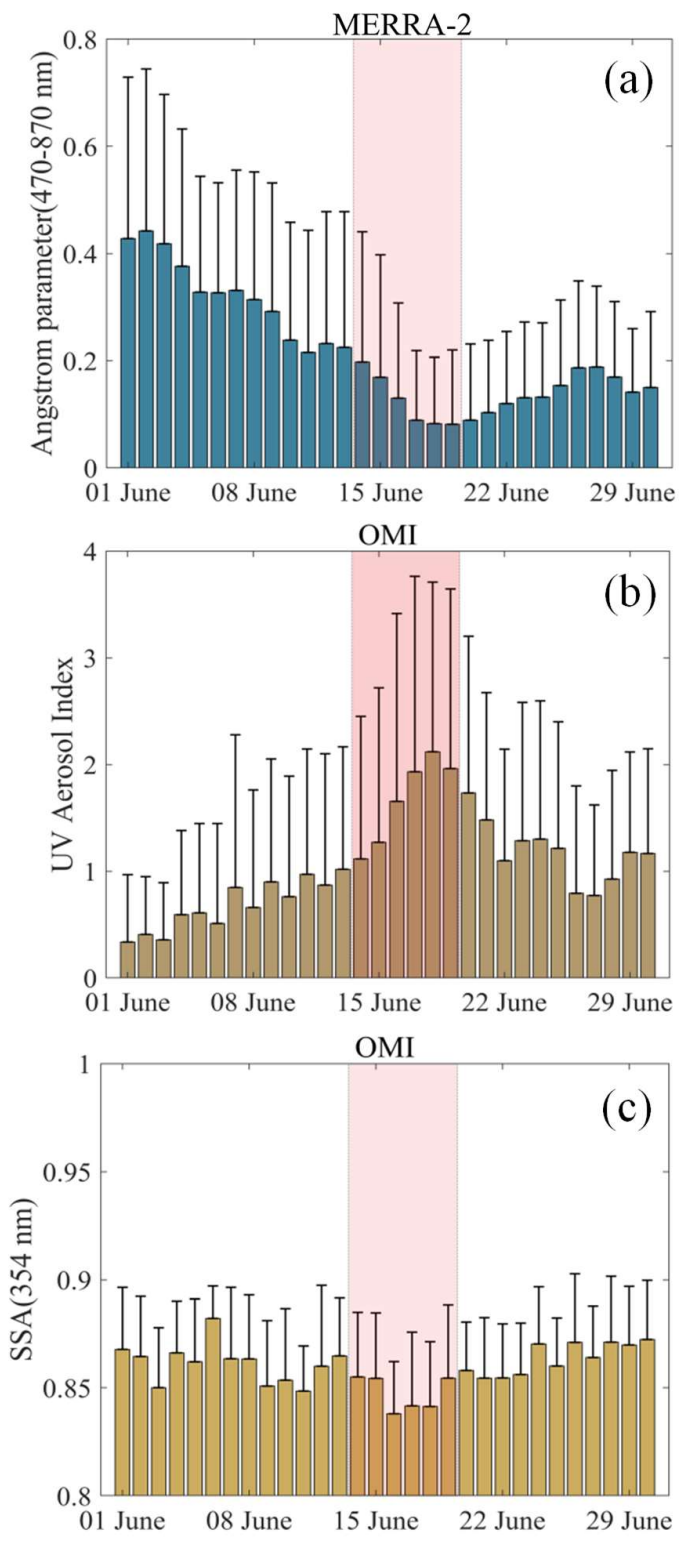

Fig.4. Area averaged time series of (a) Angstrom parameter from MERRA-2, (b) UV aerosol Index from OMI, (c) Single Scattering Albedo from OMI. The shading indicates the period of the dust storm. The error bars indicate $+1 \sigma$ of the daily datasets over the selected area of interest. 


\subsection{AOD during the dust storm}

The time-averaged cross-platform AOD values are shown in Fig.5. The MODIS AOD (Fig 5a) clearly shows the large longitudinal extent of the event. The mean AOD values for MODIS are $>2$ close to coastal North-western Africa explains the high load of aerosol/dust and the severity of the storm. A similar signature is also visible in the OMI retrieved mean AOD (Fig 5b). The model/reanalysis AOD (MERRA-2 and CAMS, Figure $5 \mathrm{c}$-d) also captures the spatial spread; however, the values are a bit underestimated as already discussed compared to the satellite observation which was also seen in area-averaged AOD values (Fig. 2).

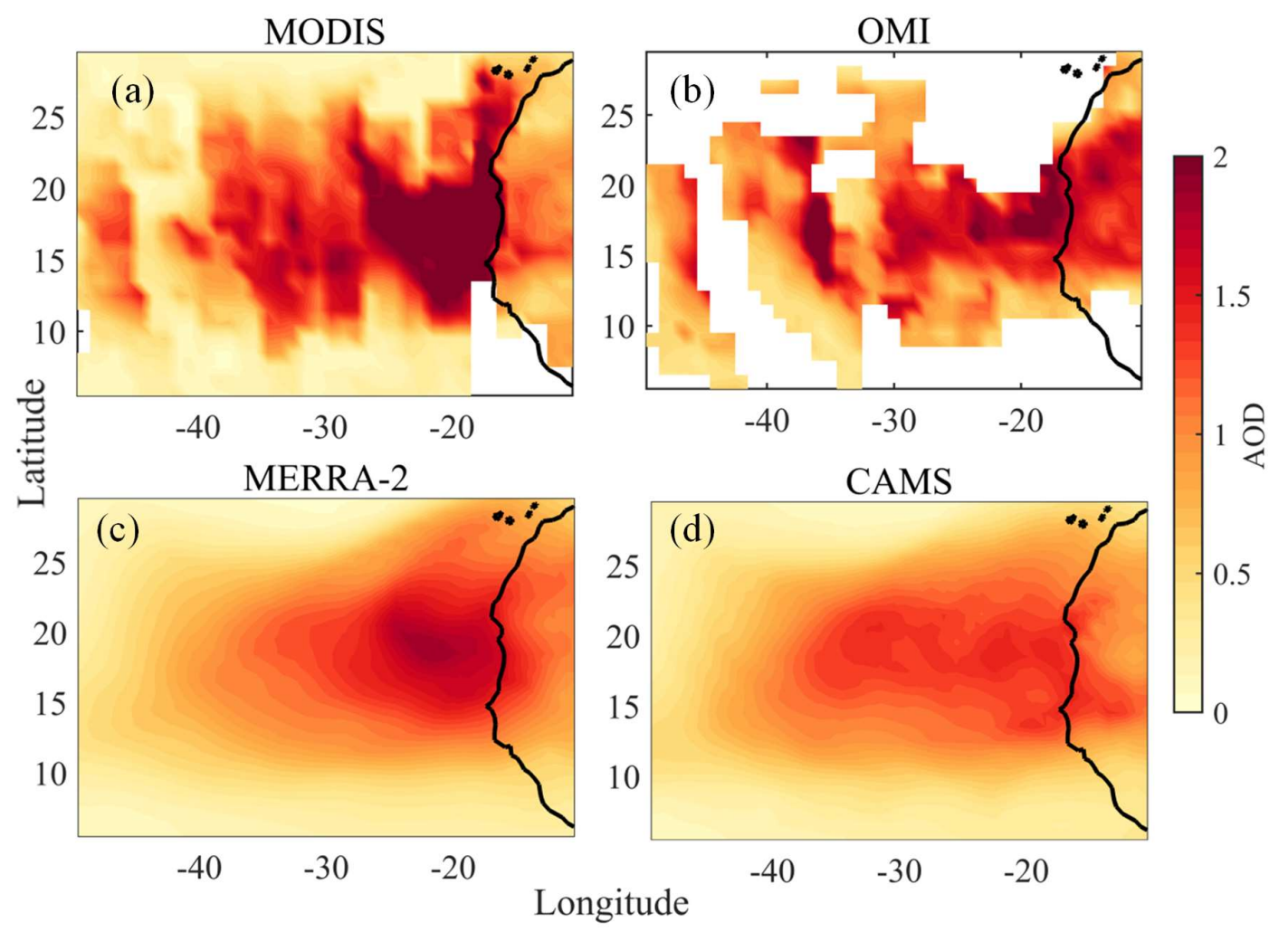

Fig.5.Time average spatial map of Aerosol optical depth (AOD) during the dust storm using datasets from (a) MODIS (b) OMI (c) MERRA-2 and (d) CAMS.

\subsection{Aerosol radiative forcing}

The time-averaged (14-19 June 2020) aerosol radiative forcing (ARF) is estimated and shown in Fig 6. The surface and top of the atmosphere as well as surface ARF are typically negative during for dust over northwestern Africa and adjacent regions (Li et al., 2004; Saidou Chaibou et al., 2020). This particular storm witnessed maximum diurnal averaged ARF at the surface as high as $-150 \mathrm{Wm}^{-2}$. The values are found to be higher close to the coastal NW Africa and adjacent oceanic region. Similarly, the TOA-ARF (Fig 6a) has its maximum values $\sim-60 \mathrm{Wm}^{-2}$. This high negative value at the surface and top of the atmosphere suggests more attenuation of incoming solar radiation due to dust backscattering. The difference between the TOA and BOA ARF gives a positive forcing (absorbing) within the atmosphere with maximum ATM ARF that goes up to $\sim 60 \mathrm{Wm}^{-2}$, suggesting a net warming effect. This ATM ARF is $\sim 200 \%$ higher (see Table -1 ) to its climatological mean, suggesting the dust intensification during the storm. Such higher ranges of aerosol radiative forcing are reported 
before for severe dust storm events (Kumar et al., 2015). Again, prolonged negative aerosol radiative forcing at the surface (net cooling effect) could have impacted the sea surface temperature over the ocean and the air-sea interactions. Also, the storm-induced change in the ATM ARF might have further affected the thermodynamics state of the atmosphere. We have discussed it separately in the subsequent section.
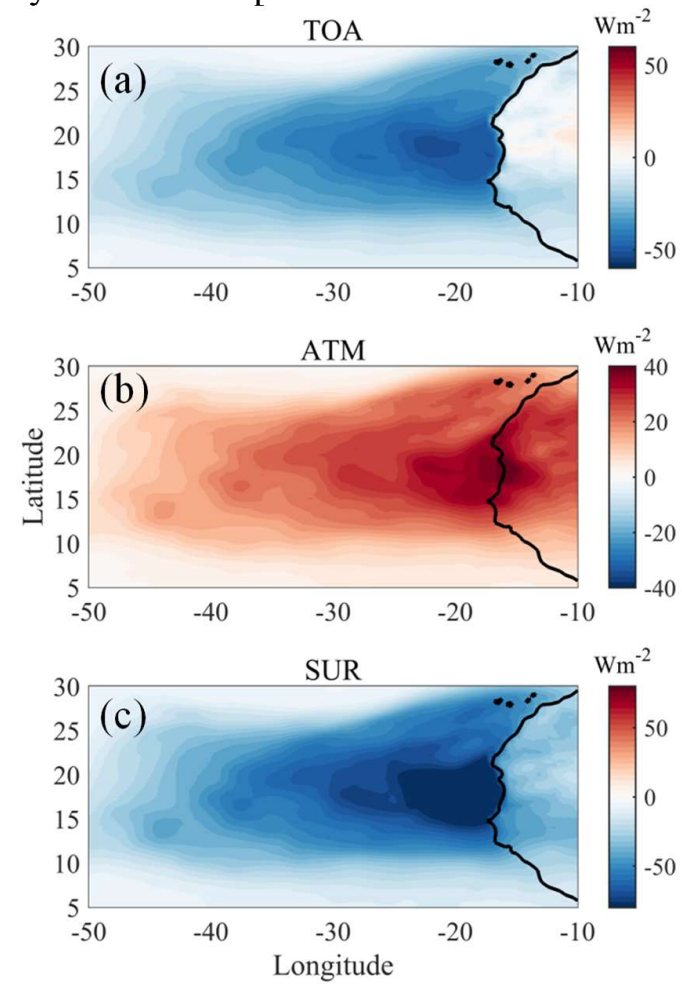

Fig. 6. Spatial map (time averaged) of ARF at (a) top of the atmosphere (b) in the atmosphere and (c) at the surface, using MERRA-2 datasets during the dust storm.

\subsection{Changes in the thermodynamics state variables in the atmosphere}

Temperature and relative humidity are two important thermodynamics variables of the atmosphere. Any change in the thermodynamic state can further impact the dynamics through changes to thermal structure of the atmosphere. Here, we have examined the changes to these parameters using AIRS datasets (Fig 6a-b). As mentioned earlier, an elevated dust layer which formed as a consequence of the dust storm, led to the warming of the atmospheric column due to the ARF response. The elevated warming signature is observed in Fig 6a just coinciding with the dust storm (marked with an arrow). The warming effect is also observed from the surface to the mid-troposphere. The warming was found to be persistent even after the dust event, which could be due to the slow removal of dust from the atmosphere (Fig. 2 and S2). At the same time, a sudden drop (please see the direction of the arrow) in the relative humidity was also observed collocated with the beginning of the storm event. This sudden drop in $\mathrm{RH}$ could be explained due to the increase in the dust induced atmospheric temperature/warming. The overall change in the mean temperature (averaged from surface to $850 \mathrm{hPa}$ ) is $\sim 8 \%$ higher (the numbers are much higher if taken for specific dust levels) than its climatological values. A relative drop in $\mathrm{RH}(-3.7 \%$, Table-1) explains the significant impact of the dust storm. An attempt is also made to observe these warming using surface based radiosonde measurements. The details are discussed in the next section. 

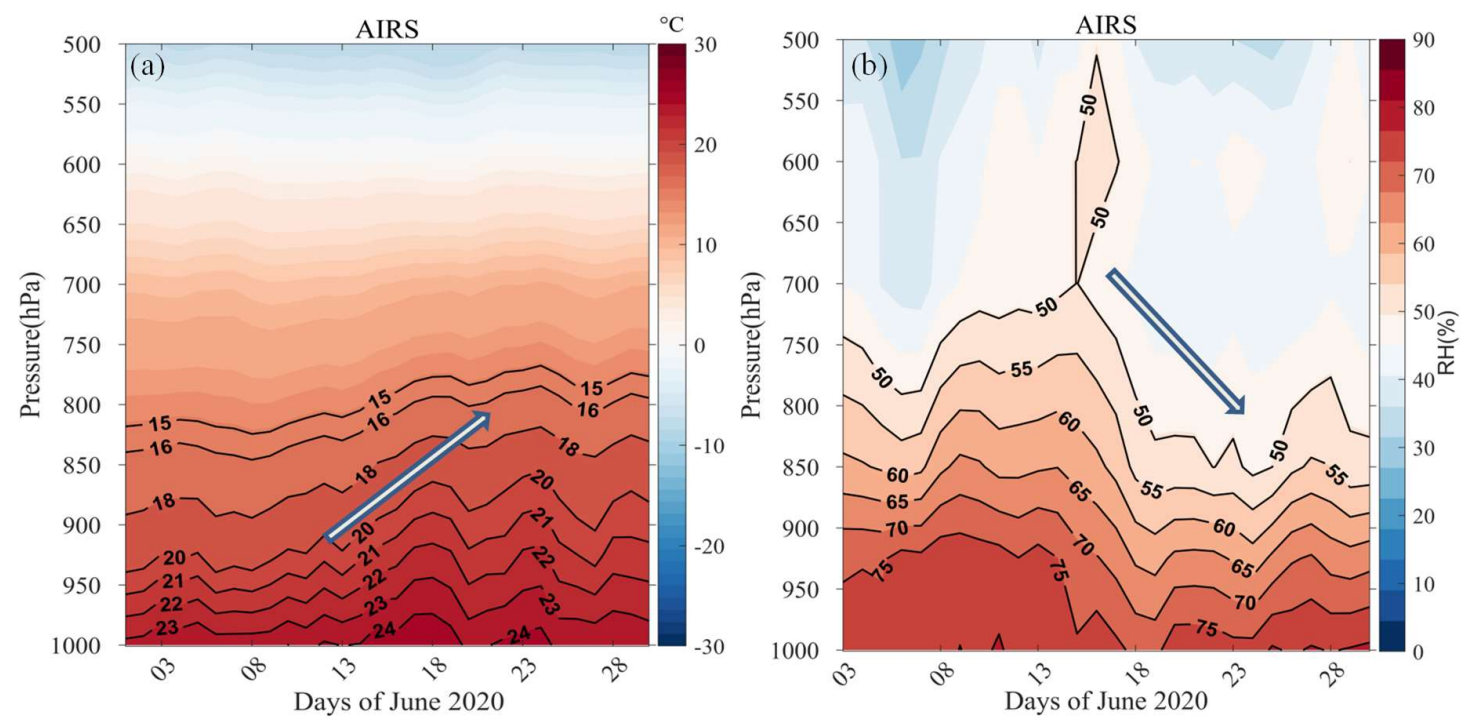

Fig.6. Area averaged time-height plot of (a) Temperature and (b) Relative humidity using AIRS during the dust storm.

\subsection{Regional changes}

The dust storm offers a unique opportunity to investigate the response of temperature and relative humidity regionally. We have used the sounding datasets at Guimar-Tenerife (Station latitude: $28.47^{\circ} \mathrm{N}$ Station longitudes: $-16.38^{\circ} \mathrm{W}$ ) which falls within the study area. The timeheight map of temperature (Fig.7) shows a distinct signature of elevated warming. The lower atmospheric column was heated up with the beginning of the dust storm (14 June 2020) and the trend continued till the end of the month. The environmental conditions like higher surface winds (Francis et al., 2020) and drier atmosphere helped the dust to remain in the atmosphere after the storm event which further amplified the post-storm warming as seen in Fig.7. The elevated warming recorded in the radiosonde derived atmospheric profiles of temperature is similar to that observed in the AIRS measurements (Fig 6a). The relative change in the temperature (averaged over the surface to $850 \mathrm{hPa}$ ) is $\sim 16.8 \%$ higher than its climatological values (Table 1). It may be mentioned that atmospheric warming may be due to several reasons other than dust induced heating such as due to cloud formation, air mass incursion etc. The analysis clearly shows the sharp rise and fall in temperature coinciding with the dust storm. The reason for post-storm warming is hence not explored further. However, it is possible that the dust remained in the atmosphere for longer and also other atmospheric processes may have had a role in the post-dust storm warming. 


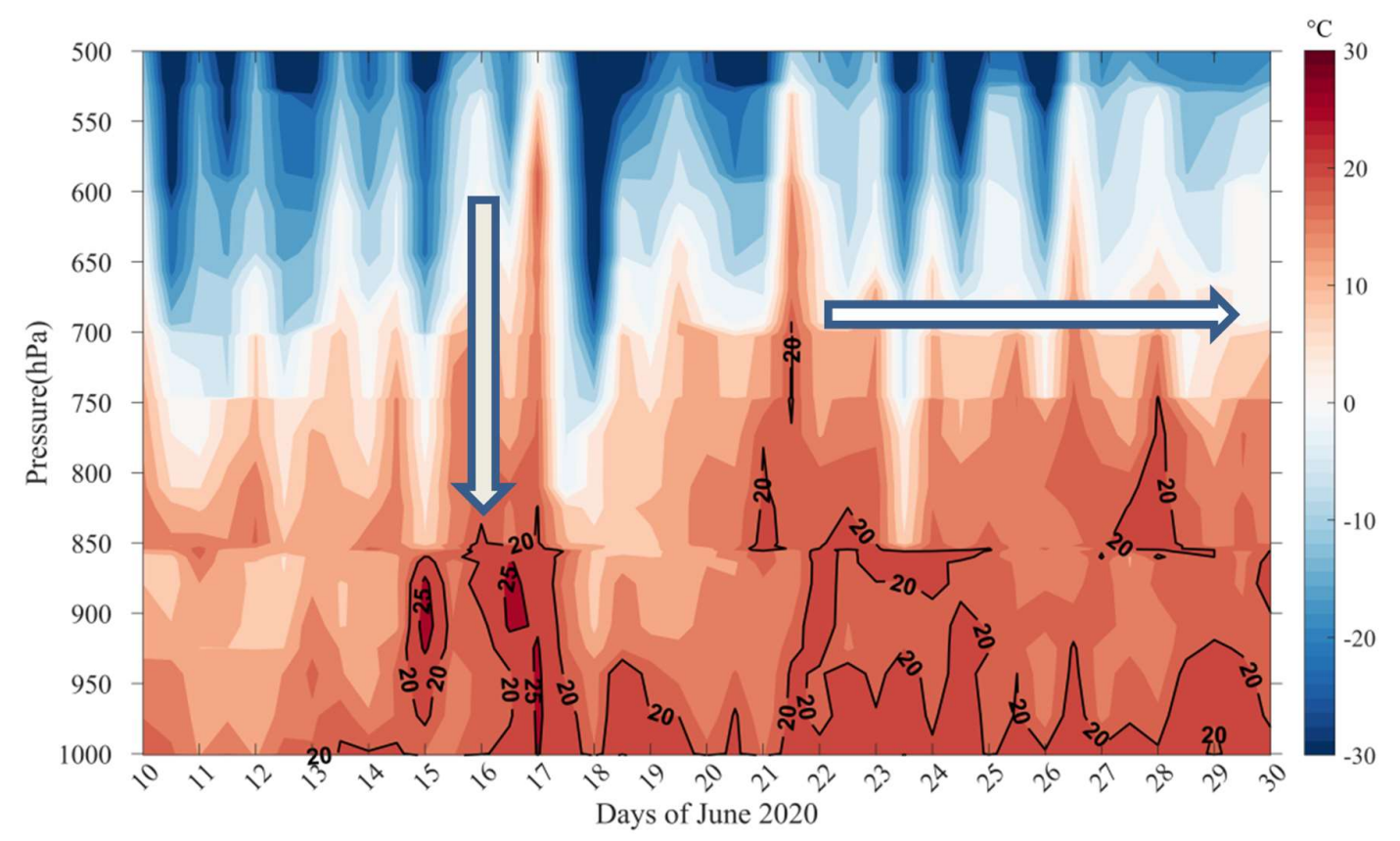

Fig.7.The time-height plot of temperature at Guimar-Tenerife (Station latitude: $28.47^{\circ} \mathrm{N}$ Station longitudes: $-16.38^{\circ} \mathrm{W}$ )

We have further investigated the six-day composite (before, during and after the dust storm event) of temperature and humidity profiles as depicted in Fig.8. A clear distinction between pre and post-storm temperature profiles is visible. The temperature during the dust storm event (black line) is comparatively higher in the lower atmosphere than that of before storm composites. This indicates an elevated dust warming which might be due to the presence of high dust load in the atmosphere. The post-storm composite (red line) is distinct in the higher altitude $(700-900 \mathrm{hPa})$ compared to the event composite temperature whereas, the surface temperature is close to each other. This signature is also clearly distinguishable in the time latitude temperature map (Fig.7). The large decline in the whole column relative humidity points to the possibility of processes other than dust storm such as dry air incursion devoid of dust during this period.
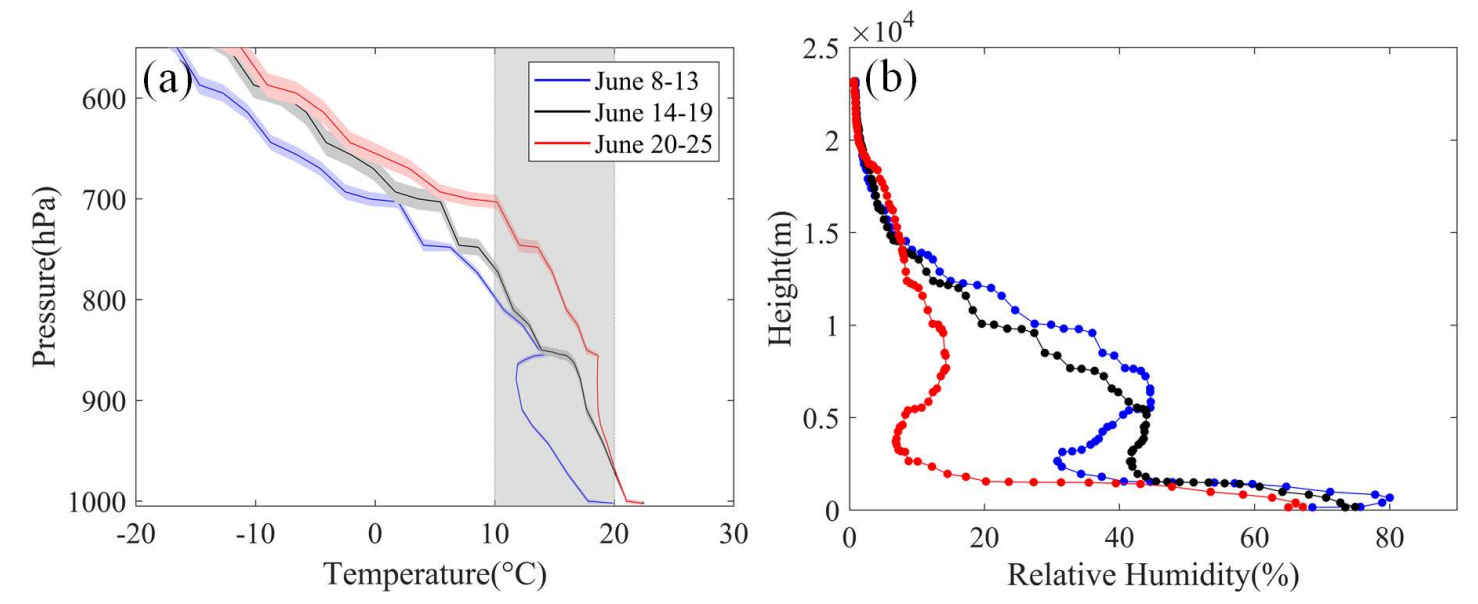

Fig. 8 (a) Six days composite (Day and night average) of pressure -temperature and (b) height-relative humidity profile (right) for pre, during the dust storm and post-event from radiosonde datasets for Guimar-Tenerife 
The relative humidity profile in Fig.8b also supports the dust induced warming signature at the lower levels of the atmosphere. Relative humidity drops with an increase in temperature. The post-event composite RH shows a remarkable drop and value are below $20 \%$ in the altitude of 0.5 to $1.5 \mathrm{~km}$. The maximum humidity change between the composites is observed at an elevation of $500 \mathrm{~m}$ from the surface. A study by Milford et al (2019) has also reported similar signatures in RH during dust outbreaks. However, it may be mentioned that the cause for the post-dust storm decline in RH throughout the column is not clear.

Table 1: Change in optical and thermodynamics parameters during dust storm w.r.to 20152019 climatology

\begin{tabular}{|c|c|c|c|c|c|}
\hline $\begin{array}{l}\text { Satellite } \\
\text { Sensors }\end{array}$ & $\begin{array}{l}\text { Model } \\
\text { Reanalysis }\end{array}$ & Variables & $\begin{array}{l}\text { Event } \\
\text { mean } \pm 1 \sigma\end{array}$ & $\begin{array}{l}\text { Climatology } \\
(\text { mean } \pm 1 \sigma)\end{array}$ & $\begin{array}{l}\text { \% Change } \\
\text { (mean) }\end{array}$ \\
\hline MODIS & & $\operatorname{AOD}(550 \mathrm{~nm})$ & $0.91 \pm 0.86$ & $0.35 \pm 0.23$ & 160 \\
\hline \multirow[t]{6}{*}{ OMI } & & $\operatorname{AOD}(500 \mathrm{~nm})$ & $1.15 \pm 0.66$ & $0.51 \pm 0.23$ & 125.5 \\
\hline & \multirow[t]{2}{*}{ CAMS } & $\operatorname{AOD}(550 \mathrm{~nm})$ & $0.71 \pm 0.58$ & $0.29 \pm 0.16$ & 144.8 \\
\hline & & DUST AOD( 550nm) & $0.53 \pm 0.5$ & $0.13 \pm 0.12$ & 307.7 \\
\hline & \multirow[t]{3}{*}{ MERRA2 } & $\operatorname{AOD}(550 \mathrm{~nm})$ & $0.74 \pm 0.63$ & $0.27 \pm 0.17$ & 174.1 \\
\hline & & DUST AOD( 550nm) & $0.67 \pm 0.6$ & $0.19 \pm 0.16$ & 252.6 \\
\hline & & ANG( 470-800) & $0.12 \pm 0.18$ & $0.3 \pm 0.2$ & -60 \\
\hline OMI & \multirow{5}{*}{ MERRA2 } & $\mathrm{AI}(360 \mathrm{~nm})$ & $1.68 \pm 1.65$ & $0.72 \pm 0.61$ & 133.3 \\
\hline \multirow[t]{4}{*}{ OMI } & & $\operatorname{SSA}(354 \mathrm{~nm})$ & $0.84+0.03$ & $0.86 \pm 0.27$ & -2.3 \\
\hline & & ARF TOA & $-20 \pm 14$ & $8.13 \pm 5.22$ & 153.4 \\
\hline & & ARF BOA & $-36 \pm 22$ & $-13.37 \pm 7.6$ & 169.3 \\
\hline & & ARF ATM & $15.4 \pm 101$ & $5.54 \pm 3.65$ & 193.9 \\
\hline AIRS & & Temperature & $21.7 \pm 4$ & $20.1 \pm 3.18$ & 8 \\
\hline AIRS & & Relative humidity $(\mathrm{RH})$ & $64.5 \pm 21.2$ & $67 \pm 20$ & -3.7 \\
\hline \multirow[t]{2}{*}{ Radiosonde } & & Temperature & $18.39 \pm 4.8$ & $15.75 \pm 2.77$ & 16.8 \\
\hline & & Relative Humidity $(\mathrm{RH})$ & $72.3 \pm 15$ & $73.9 \pm 9.5$ & -2.16 \\
\hline
\end{tabular}

\subsection{Summary and conclusion}

The present study is focused on characterising the radiative and thermodynamics impacts of the historical Saharan dust storm (by June standard) during 14-19 June 2020. Strong northwesterly near-surface winds triggered the event due to pressure distribution over part of the Atlantic Ocean and northwestern Africa. These features were reported to be part of a global circumpolar northern hemispheric wave train during June (Francis et al., 2020). The dust storm event is investigated using state of the art satellite-derived products and high-resolution model reanalysis. The main findings of this work are summarized as follows.

1. The BSC-Dream model simulations, as well as satellite true colour images, showed the extreme nature of the dust storm that originated over the Sahara desert.

2. The multiplatform analysis shows fair agreements between the model and satellitederived AOD that showed values of as high as 2 during the event. More than $98 \%$ of variabilities in the total AOD were explained by Dust (Dust AOD) prove the presence of intense dust load in the atmospheric column. The spatial extent and magnitude between reanalysis and satellite AOD shows good agreement with each other. 
3. High values of AOD $(\sim 2)$ and low ANG $(\sim 0.1)$ were observed during the peak of the dust storm event (17 June 2020). The lower ANG values suggest the dominance of coarse mode dust particle in the atmosphere. The change in AOD was more than $150 \%$ (MODIS and MERRA2) whereas; DUST AOD change was $250 \%$ (table-1) compared to its climatology.

4. The higher value of UVAI observation signifies the presence of elevated dust. The CALIPSO data (Fig S4) also shows the vertical dust extent far up to $5 \mathrm{~km}$ altitude.

5. The maximum aerosol radiative forcing at the surface surged up to $-150 \mathrm{Wm}^{-2}$ and. and almost $-80 \mathrm{Wm}^{-2}$ at the top of the atmosphere near the dust source region. Such large radiative imbalances result an atmospheric forcing/warming which is $\sim 200 \%$ more than its mean climatology. Such a huge change in atmospheric radiative forcing is sufficient to affect atmospheric dynamics and thermodynamics.

6. The response of the dust storm is visible in the atmospheric thermodynamic state variables. There is more than $16 \%$ increment in the temperature, and a $2 \%$ drop in relative humidity is observed (from the climatological mean) at a radiosonde site Guimar-Tenerife. A similar signature is also observed from AIRS satellite observation.

\section{Declaration of competing interests}

The authors declare that they have no competing interests

\section{Acknowledgement}

The authors are grateful to Director NCPOR for constant encouragement and support. The authors are also thankful to Giovanni, NASA for freely providing satellite measured aerosol and other data products. We acknowledge University of Wyoming for giving radiosonde datasets

\section{CRediT authorship contribution statement}

A Asutosh: Conceptualization, sample analysis, writing- original draft preparation V Vinoj: Conceptualization, Writing, reviewing and editing

M Nuncio: Writing, reviewing and editing

\section{Data and codes}

Datasets are freely available and can be downloadable from the internet. The codes can be shared upon request to the corresponding author 


\section{References}

Aher, G.R., Pawar, G. V., Gupta, P., Devara, P.C.S., 2014. Effect of major dust storm on optical, physical, and radiative properties of aerosols over coastal and urban environments in Western India. Int. J. Remote Sens. 35, 871-903. https://doi.org/10.1080/01431161.2013.873153

Ajtai, N., Ștefănie, H., Mereuță, A., Radovici, A., Botezan, C., 2020. Multi-Sensor Observation of a Saharan Dust Outbreak over Transylvania, Romania in April 2019. Atmosphere (Basel). 11, 364. https://doi.org/10.3390/atmos11040364

Akinyoola, J.A., Ajayi, V.O., Abiodun, B.J., Ogunjobi, K.O., Gbode, I.E., Ogungbenro, S.B., 2019. Dynamic response of monsoon precipitation to mineral dust radiative forcing in the West Africa region. Model. Earth Syst. Environ. https://doi.org/10.1007/s40808-01900620-Z

Alam, K., Trautmann, T., Blaschke, T., Majid, H., 2012. Aerosol optical and radiative properties during summer and winter seasons over Lahore and Karachi. Atmos. Environ. 50, 234-245. https://doi.org/10.1016/j.atmosenv.2011.12.027

Amiridis, V., Balis, D.S., Giannakaki, E., Stohl, A., Kazadzis, S., Koukouli, M.E., Zanis, P., 2009. Optical characteristics of biomass burning aerosols over Southeastern Europe determined from UV-Raman lidar measurements. Atmos. Chem. Phys. 9, 2431-2440. https://doi.org/10.5194/acp-9-2431-2009

Badarinath, K.V.S., Kharol, S.K., Kaskaoutis, D.G., Sharma, A.R., Ramaswamy, V., Kambezidis, H.D., 2010. Long-range transport of dust aerosols over the Arabian Sea and Indian region - A case study using satellite data and ground-based measurements. Glob. Planet. Change 72, 164-181. https://doi.org/10.1016/j.gloplacha.2010.02.003

Basart, S., Pérez, C., Nickovic, S., Cuevas, E., Baldasano, J., 2012. Development and evaluation of the BSC-DREAM8b dust regional model over Northern Africa, the Mediterranean and the Middle East. Tellus B Chem. Phys. Meteorol. 64, 18539. https://doi.org/10.3402/tellusb.v64i0.18539

Bergstrom, R.W., Pilewskie, P., Russell, P.B., Redemann, J., Bond, T.C., Quinn, P.K., Sierau, B., 2007. Spectral absorption properties of atmospheric aerosols. Atmos. Chem. Phys. 7, 5937-5943. https://doi.org/10.5194/acp-7-5937-2007

Bou Karam, D., Williams, E., Janiga, M., Flamant, C., Mcgraw-Herdeg, M., Cuesta, J., Auby, A., Thorncroft, C., 2014. Synoptic-scale dust emissions over the Sahara Desert initiated by a moist convective cold pool in early August 2006. Q. J. R. Meteorol. Soc. 140, 2591-2607. https://doi.org/10.1002/qj.2326

Bran, S.H., Jose, S., Srivastava, R., 2018. Investigation of optical and radiative properties of aerosols during an intense dust storm: A regional climate modeling approach. J. Atmos. Solar-Terrestrial Phys. 168, 21-31. https://doi.org/10.1016/j.jastp.2018.01.003

Buchard, V., Randles, C.A., da Silva, A.M., Darmenov, A., Colarco, P.R., Govindaraju, R., Ferrare, R., Hair, J., Beyersdorf, A.J., Ziemba, L.D., Yu, H., 2017. The MERRA-2 aerosol reanalysis, 1980 onward. Part II: Evaluation and case studies. J. Clim. 30, 68516872. https://doi.org/10.1175/JCLI-D-16-0613.1

Curier, R.L., Veefkind, J.P., Braak, R., Veihelmann, B., Torres, O., de Leeuw, G., 2008. 
Retrieval of aerosol optical properties from OMI radiances using a multiwavelength algorithm: Application to western Europe. J. Geophys. Res. Atmos. 113. https://doi.org/10.1029/2007JD008738

Dessler, A.E., Zhang, Z., Yang, P., 2008. Water-vapor climate feedback inferred from climate fluctuations, 2003-2008. Geophys. Res. Lett. 35, L20704.

https://doi.org/10.1029/2008GL035333

Dey, S., Tripathi, S.N., Singh, R.P., Holben, B.N., 2004. Influence of dust storms on the aerosol optical properties over the Indo-Gangetic basin. J. Geophys. Res. D Atmos. 109, D20211. https://doi.org/10.1029/2004JD004924

Engelstaedter, S., Tegen, I., Washington, R., 2006. North African dust emissions and transport. Earth-Science Rev. 79, 73-100. https://doi.org/10.1016/j.earscirev.2006.06.004

Filonchyk, M., Yan, H., Shareef, T.M.E., Yang, S., 2019. Aerosol contamination survey during dust storm process in Northwestern China using ground, satellite observations and atmospheric modeling data. Theor. Appl. Climatol. 135, 119-133. https://doi.org/10.1007/s00704-017-2362-8

Francis, D., Fonseca, R., Nelli, N., Cuesta, J., Weston, M., Evan, A., Temimi, M., 2020. The Atmospheric Drivers of the Major Saharan Dust Storm in June 2020. Geophys. Res. Lett. 47, e2020GL090102. https://doi.org/10.1029/2020GL090102

Fung, I.Y., Meyn, S.K., Tegen, I., Doney, S.C., John, J.G., Bishop, J.K.B., 2000. Iron supply and demand in the upper ocean. Global Biogeochem. Cycles 14, 281-295. https://doi.org/10.1029/1999gb900059

Gautam, R., Hsu, N.C., Tsay, S.C., Lau, K.M., Holben, B., Bell, S., Smirnov, A., Li, C., Hansell, R., Ji, Q., Payra, S., Aryal, D., Kayastha, R., Kim, K.M., 2011. Accumulation of aerosols over the Indo-Gangetic plains and southern slopes of the Himalayas: Distribution, properties and radiative effects during the 2009 pre-monsoon season. Atmos. Chem. Phys. 11, 12841-12863. https://doi.org/10.5194/acp-11-12841-2011

Gautam, R., Liu, Z., Singh, R.P., Hsu, N.C., 2009. Two contrasting dust-dominant periods over India observed from MODIS and CALIPSO data. Geophys. Res. Lett. 36. https://doi.org/10.1029/2008GL036967

Gelaro, R., McCarty, W., Suárez, M.J., Todling, R., Molod, A., Takacs, L., Randles, C.A., Darmenov, A., Bosilovich, M.G., Reichle, R., Wargan, K., Coy, L., Cullather, R., Draper, C., Akella, S., Buchard, V., Conaty, A., da Silva, A.M., Gu, W., Kim, G.K., Koster, R., Lucchesi, R., Merkova, D., Nielsen, J.E., Partyka, G., Pawson, S., Putman, W., Rienecker, M., Schubert, S.D., Sienkiewicz, M., Zhao, B., 2017. The modern-era retrospective analysis for research and applications, version 2 (MERRA-2). J. Clim. 30, 5419-5454. https://doi.org/10.1175/JCLI-D-16-0758.1

Gharai, B., Jose, S., Mahalakshmi, D. V., 2013. Monitoring intense dust storms over the Indian region using satellite data - a case study. Int. J. Remote Sens. 34, 7038-7048. https://doi.org/10.1080/01431161.2013.813655

Ginoux, P., Prospero, J.M., Gill, T.E., Hsu, N.C., Zhao, M., 2012. Global-scale attribution of anthropogenic and natural dust sources and their emission rates based on MODIS Deep 
Blue aerosol products. Rev. Geophys. https://doi.org/10.1029/2012RG000388

Goudie, A.S., Middleton, N.J., 2001. Saharan dust storms: Nature and consequences. EarthScience Rev. 56, 179-204. https://doi.org/10.1016/S0012-8252(01)00067-8

Haustein, K., Pérez, C., Baldasano, J.M., Müller, D., Tesche, M., Schladitz, A., Esselborn, M., Weinzierl, B., Kandler, K., Von Hoyningen-Huene, W., 2009. Regional dust model performance during SAMUM 2006. Geophys. Res. Lett. 36. https://doi.org/10.1029/2008GL036463

Haywood, J.M., Allan, R.P., Culverwell, I., Slingo, T., Milton, S., Edwards, J., Clerbaux, N., 2005. Can desert dust explain the outgoing longwave radiation anomaly over the Sahara during July 2003? J. Geophys. Res. D Atmos. 110, 1-14. https://doi.org/10.1029/2004JD005232

Heidinger, A.K., Foster, M.J., Walther, A., Zhao, X., 2014. The pathfinder atmospheresextended avhrr climate dataset. Bull. Am. Meteorol. Soc. 95, 909-922. https://doi.org/10.1175/BAMS-D-12-00246.1

Herman, J.R., Bhartia, P.K., Torres, O., Hsu, C., Seftor, C., Celarier, E., 1997. Global distribution of UV-absorbing aerosols from Nimbus 7/TOMS data. J. Geophys. Res. Atmos. 102, 16911-16922. https://doi.org/10.1029/96jd03680

Holben, B.N., Eck, T.F., Slutsker, I., Tanré, D., Buis, J.P., Setzer, A., Vermote, E., Reagan, J.A., Kaufman, Y.J., Nakajima, T., Lavenu, F., Jankowiak, I., Smirnov, A., 1998. AERONET - A federated instrument network and data archive for aerosol characterization. Remote Sens. Environ. 66, 1-16. https://doi.org/10.1016/S00344257(98)00031-5

Hsu, N.C., Herman, J.R., Torres, O., Holben, B.N., Tanre, D., Eck, T.F., Smirnov, A., Chatenet, B., Lavenu, F., 1999. Comparisons of the TOMS aerosol index with Sunphotometer aerosol optical thickness: Results and applications. J. Geophys. Res. Atmos. https://doi.org/10.1029/1998JD200086

Hsu, N.C., Herman, J.R., Weaver, C., 2000. Determination of radiative forcing of Saharan dust using combined TOMS and ERBE data. J. Geophys. Res. Atmos. 105. https://doi.org/10.1029/2000jd900150

Inness, A., Baier, F., Benedetti, A., Bouarar, I., Chabrillat, S., Clark, H., Clerbaux, C., Coheur, P., Engelen, R.J., Errera, Q., Flemming, J., George, M., Granier, C., HadjiLazaro, J., Huijnen, V., Hurtmans, D., Jones, L., Kaiser, J.W., Kapsomenakis, J., Lefever, K., Leitão, J., Razinger, M., Richter, A., Schultz, M.G., Simmons, A.J., Suttie, M., Stein, O., Thépaut, J.N., Thouret, V., Vrekoussis, M., Zerefos, C., 2013. The MACC reanalysis: An 8 yr data set of atmospheric composition. Atmos. Chem. Phys. https://doi.org/10.5194/acp-13-4073-2013

Jickells, T.D., An, Z.S., Andersen, K.K., Baker, A.R., Bergametti, C., Brooks, N., Cao, J.J., Boyd, P.W., Duce, R.A., Hunter, K.A., Kawahata, H., Kubilay, N., LaRoche, J., Liss, P.S., Mahowald, N., Prospero, J.M., Ridgwell, A.J., Tegen, I., Torres, R., 2005. Global iron connections between desert dust, ocean biogeochemistry, and climate. Science (80-. ). https://doi.org/10.1126/science.1105959

Kahn, R.A., Gaitley, B.J., Martonchik, J. V., Diner, D.J., Crean, K.A., Holben, B., 2005. 
Multiangle Imaging Spectroradiometer (MISR) global aerosol optical depth validation based on 2 years of coincident Aerosol Robotic Network (AERONET) observations. J. Geophys. Res. D Atmos. 110, 1-16. https://doi.org/10.1029/2004JD004706

Kaskaoutis, D.G., Kalapureddy, M.C.R., Krishna Moorthy, K., Devara, P.C.S., Nastos, P.T., Kosmopoulos, P.G., Kambezidis, H.D., 2010. Heterogeneity in pre-monsoon aerosol types over the Arabian Sea deduced from ship-borne measurements of spectral AODs. Atmos. Chem. Phys. 10, 4893-4908. https://doi.org/10.5194/acp-10-4893-2010

Kaskaoutis, D.G., Kambezidis, H.D., Hatzianastassiou, N., Kosmopoulos, P.G., Badarinath, K.V.S., 2007. Aerosol climatology: dependence of the Angstrom exponent on wavelength over four AERONET sites. Atmos. Chem. Phys. Discuss. 7, 7347-7397. https://doi.org/10.5194/acpd-7-7347-2007

Kaskaoutis, D.G., Sinha, P.R., Vinoj, V., Kosmopoulos, P.G., Tripathi, S.N., Misra, A., Sharma, M., Singh, R.P., 2013. Aerosol properties and radiative forcing over Kanpur during severe aerosol loading conditions. Atmos. Environ. 79, 7-19. https://doi.org/10.1016/j.atmosenv.2013.06.020

Kedia, S., Kumar, R., Islam, S., Sathe, Y., Kaginalkar, A., 2018. Radiative impact of a heavy dust storm over India and surrounding oceanic regions. Atmos. Environ. 185, 109-120. https://doi.org/10.1016/j.atmosenv.2018.05.005

Kinne, S., Schulz, M., Textor, C., Guibert, S., Balkanski, Y., Bauer, S.E., Berntsen, T., Berglen, T.F., Boucher, O., Chin, M., Collins, W., Dentener, F., Diehl, T., Easter, R., Feichter, J., Fillmore, D., Ghan, S., Ginoux, P., Gong, S., Grini, A., Hendricks, J., Herzog, M., Horowitz, L., Isaksen, I., Iversen, T., Kirkevåg, A., Kloster, S., Koch, D., Kristjansson, J.E., Krol, M., Lauer, A., Lamarque, J.F., Lesins, G., Liu, X., Lohmann, U., Montanaro, V., Myhre, G., Penner, J.E., Pitari, G., Reddy, S., Seland, O., Stier, P., Takemura, T., Tie, X., 2006. An AeroCom initial assessment - Optical properties in aerosol component modules of global models. Atmos. Chem. Phys. 6, 1815-1834. https://doi.org/10.5194/acp-6-1815-2006

Kumar, Sarvan, Kumar, Sanjay, Kaskaoutis, D.G., Singh, R.P., Singh, R.K., Mishra, A.K., Srivastava, M.K., Singh, A.K., 2015. Meteorological, atmospheric and climatic perturbations during major dust storms over Indo-Gangetic Basin. Aeolian Res. 17, 1531. https://doi.org/10.1016/j.aeolia.2015.01.006

Levelt, P.F., Van Den Oord, G.H.J., Dobber, M.R., Mälkki, A., Visser, H., De Vries, J., Stammes, P., Lundell, J.O.V., Saari, H., 2006. The ozone monitoring instrument. IEEE Trans. Geosci. Remote Sens. 44, 1093-1100. https://doi.org/10.1109/TGRS.2006.872333

Levy, R.C., Remer, L.A., Kleidman, R.G., Mattoo, S., Ichoku, C., Kahn, R., Eck, T.F., 2010. Global evaluation of the Collection 5 MODIS dark-target aerosol products over land. Atmos. Chem. Phys. 10, 10399-10420. https://doi.org/10.5194/acp-10-10399-2010

Li, F., Vogelmann, A.M., Ramanathan, V., 2004. Saharan dust aerosol radiative forcing measured from space. J. Clim. 17, 2558-2571. https://doi.org/10.1175/15200442(2004)017<2558:SDARFM $>2.0 . \mathrm{CO} ; 2$

Mahowald, N.M., Kloster, S., Engelstaedter, S., Moore, J.K., Mukhopadhyay, S., McConnell, J.R., Albani, S., Doney, S.C., Bhattacharya, A., Curran, M.A.J., Flanner, M.G., 
Hoffman, F.M., Lawrence, D.M., Lindsay, K., Mayewski, P.A., Neff, J., Rothenberg, D., Thomas, E., Thornton, P.E., Zender, C.S., 2010. Observed 20th century desert dust variability: Impact on climateand biogeochemistry. Atmos. Chem. Phys. 10, 1087510893. https://doi.org/10.5194/acp-10-10875-2010

Milford, C., Cuevas, E., Marrero, C.L., Bustos, J.J., Gallo, V., Rodríguez, S., RomeroCampos, P.M., Torres, C., 2019. Impacts of Desert Dust Outbreaks on Air Quality in Urban Areas. Atmosphere (Basel). 11, 23. https://doi.org/10.3390/atmos11010023

Molod, A., Takacs, L., Suarez, M., Bacmeister, J., 2015. Development of the GEOS-5 atmospheric general circulation model: Evolution from MERRA to MERRA2. Geosci. Model Dev. 8, 1339-1356. https://doi.org/10.5194/gmd-8-1339-2015

Namdari, S., Karimi, N., Sorooshian, A., Mohammadi, G.H., Sehatkashani, S., 2018. Impacts of climate and synoptic fluctuations on dust storm activity over the Middle East. Atmos. Environ. 173, 265-276. https://doi.org/10.1016/j.atmosenv.2017.11.016

Nickovic, S., Kallos, G., Papadopoulos, A., Kakaliagou, O., 2001. A model for prediction of desert dust cycle in the atmosphere. J. Geophys. Res. Atmos. 106, 18113-18129. https://doi.org/10.1029/2000JD900794

Pakszys, P., Zielinski, T., 2017. Aerosol optical properties over Svalbard: a comparison between Ny-Ålesund and Hornsund. Oceanologia 59, 431-444. https://doi.org/10.1016/j.oceano.2017.05.002

Pan, B., Wang, Y., Hu, J., Lin, Y., Hsieh, J.S., Logan, T., Feng, X., Jiang, J.H., Yung, Y.L., Zhang, R., 2018. Impacts of Saharan dust on Atlantic regional climate and implications for tropical cyclones. J. Clim. 31, 7621-7644. https://doi.org/10.1175/JCLI-D-16-0776.1

Pandey, S.K., Vinoj, V., Landu, K., Babu, S.S., 2017. Declining pre-monsoon dust loading over South Asia: Signature of a changing regional climate. Sci. Rep. 7, 1-10. https://doi.org/10.1038/s41598-017-16338-w

Penna, B., Herdies, D., Costa, S., 2018. Estimates of direct radiative forcing due to aerosols from the MERRA-2 reanalysis over the Amazon region. Atmos. Chem. Phys. Discuss. 1-17. https://doi.org/10.5194/acp-2018-355

Pérez, C., Nickovic, S., Baldasano, J.M., Sicard, M., Rocadenbosch, F., Cachorro, V.E., 2006. A long Saharan dust event over the western Mediterranean: Lidar, Sun photometer observations, and regional dust modeling. J. Geophys. Res. Atmos. 111.

https://doi.org/10.1029/2005JD006579

Prasad, A.K., Singh, S., Chauhan, S.S., Srivastava, M.K., Singh, R.P., Singh, R., 2007. Aerosol radiative forcing over the Indo-Gangetic plains during major dust storms. Atmos. Environ. 41, 6289-6301. https://doi.org/10.1016/j.atmosenv.2007.03.060

Prijith, S.S., Rajeev, K., Thampi, B. V., Nair, S.K., Mohan, M., 2013. Multi-year observations of the spatial and vertical distribution of aerosols and the genesis of abnormal variations in aerosol loading over the Arabian Sea during Asian summer monsoon season. J. Atmos. Solar-Terrestrial Phys. 105-106, 142-151. https://doi.org/10.1016/j.jastp.2013.09.009

Proestakis, E., Amiridis, V., Marinou, E., Georgoulias, A.K., Solomos, S., Kazadzis, S., 
Chimot, J., Che, H., Alexandri, G., Binietoglou, I., Daskalopoulou, V., Kourtidis, K.A., De Leeuw, G., Van Der A, R.J., 2018. Nine-year spatial and temporal evolution of desert dust aerosols over South and East Asia as revealed by CALIOP. Atmos. Chem. Phys. 18, 1337-1362. https://doi.org/10.5194/acp-18-1337-2018

Querol, X., Pey, J., Pandolfi, M., Alastuey, A., Cusack, M., Pérez, N., Moreno, T., Viana, M., Mihalopoulos, N., Kallos, G., Kleanthous, S., 2009. African dust contributions to mean ambient PM10 mass-levels across the Mediterranean Basin. Atmos. Environ. 43, 42664277. https://doi.org/10.1016/j.atmosenv.2009.06.013

Remer, L.A., Kaufman, Y.J., Tanré, D., Mattoo, S., Chu, D.A., Martins, J. V., Li, R.R., Ichoku, C., Levy, R.C., Kleidman, R.G., Eck, T.F., Vermote, E., Holben, B.N., 2005. The MODIS aerosol algorithm, products, and validation. J. Atmos. Sci. 62, 947-973. https://doi.org/10.1175/JAS3385.1

Saidou Chaibou, A.A., Ma, X., Sha, T., 2020. Dust radiative forcing and its impact on surface energy budget over West Africa. Sci. Rep. 10, 12236. https://doi.org/10.1038/s41598020-69223-4

Sanap, S.D., 2021. Global and regional variations in aerosol loading during COVID-19 imposed lockdown. Atmos. Environ. 246, 118132. https://doi.org/10.1016/j.atmosenv.2020.118132

Satheesh, S.K., Torres, O., Remer, L.A., Babu, S.S., Vinoj, V., Eck, T.F., Kleidman, R.G., Holben, B.N., 2009. Improved assessment of aerosol absorption using OMI-MODIS joint retrieval. J. Geophys. Res. 114, D05209. https://doi.org/10.1029/2008JD011024

Singh, A., Kumar, S., George, J.P., 2016. Dust forecast over North Africa: verification with satellite and ground based observations, in: Im, E., Kumar, R., Yang, S. (Eds.), Remote Sensing of the Atmosphere, Clouds, and Precipitation VI. SPIE, p. 98762I. https://doi.org/10.1117/12.2223596

Țîmpu, S., Sfîcă, L., Dobri, R.-V., Cazacu, M.-M., Nita, A.-I., Birsan, M.-V., 2020. Tropospheric Dust and Associated Atmospheric Circulations over the Mediterranean Region with Focus on Romania's Territory. Atmosphere (Basel). 11, 349. https://doi.org/10.3390/atmos11040349

Tiwari, S., Kumar, A., Pratap, V., Singh, A.K., 2019. Assessment of two intense dust storm characteristics over Indo - Gangetic basin and their radiative impacts: A case study. Atmos. Res. 228, 23-40. https://doi.org/10.1016/j.atmosres.2019.05.011

Tiwari, S., Srivastava, A.K., Singh, A.K., Singh, S., 2015. Identification of aerosol types over Indo-Gangetic Basin: implications to optical properties and associated radiative forcing. Environ. Sci. Pollut. Res. 22, 12246-12260. https://doi.org/10.1007/s11356-015-4495-6

Torres, O., Tanskanen, A., Veihelmann, B., Ahn, C., Braak, R., Bhartia, P.K., Veefkind, P., Levelt, P., 2007. Aerosols and surface UV products form Ozone Monitoring Instrument observations: An overview. J. Geophys. Res. Atmos. https://doi.org/10.1029/2007JD008809

Touré, N.E., Konaré, A., Silué, S., 2012. Intercontinental transport and climatic impact of saharan and sahelian dust. Adv. Meteorol. 2012. https://doi.org/10.1155/2012/157020 
Tulet, P., Mallet, M., Pont, V., Pelon, J., Boone, A., 2008. The 7-13 March 2006 dust storm over West Africa: Generation, transport, and vertical stratification. J. Geophys. Res. Atmos. 113. https://doi.org/10.1029/2008JD009871

Vinoj, V., Rasch, P.J., Wang, H., Yoon, J.H., Ma, P.L., Landu, K., Singh, B., 2014. Shortterm modulation of Indian summer monsoon rainfall by West Asian dust. Nat. Geosci. 7, 308-313. https://doi.org/10.1038/ngeo2107

Von Engeln, A., Teixeira, J., 2013. A planetary boundary layer height climatology derived from ECMWF reanalysis data. J. Clim. 26, 6575-6590. https://doi.org/10.1175/JCLI-D$12-00385.1$

W Wang, A.E.C.F.C.L., 2015. On the Decadal Scale Correlation between African Dust and Sahel Rainfall: the Role of Saharan Heat Low-Forced Winds. Sci. Adv. 1, 1-5.

Winker, D.M., Pelon, J.R., McCormick, M.P., 2003. The CALIPSO mission: spaceborne lidar for observation of aerosols and clouds, in: Lidar Remote Sensing for Industry and Environment Monitoring III. SPIE, p. 1. https://doi.org/10.1117/12.466539

Yue, Q., Lambrigtsen, B., Blaisdell, J.M., Farahmand, A., Fetzer, E.J., Fishbein, E., Griffin, E., Iredell, L., Irion, F.W., Kahn, B.H., Kalmus, P., Manning, E., Marchetti, Y., Pagano, T., Smith, N., Susskind, J., Teixeira, J., Thrastarson, H.T., Wang, T., Wen, Y., Wilson, R.C., Wong, S., 2020. AIRS Version 7 Level 2 Performance Test and Validation Report.

Zhang, X., Lu, N., Jiang, H., Yao, L., 2020. Evaluation of Reanalysis Surface Incident Solar Radiation Data in China. Sci. Rep. 10, 1-20. https://doi.org/10.1038/s41598-020-604601 